\title{
PENERAPAN NILAI-NILAI KEARIFAN LOKAL DALAM BUDAYA MASYARAKAT KAMPUNG ADAT CIREUNDEU SEBAGAI SUMBER PEMBELAJARAN IPS
}

\author{
Triani Widyanti, Prodi Pendidikan IPS, SPs, UPI
}

\begin{abstract}
ABSTRAK
Pembelajaran IPS melalui penerapan nilai-nilai kearifan lokal merupakan suatu upaya untuk menanamkan rasa kepedulian terhadap sesama, meluaskan pengetahuan tentang budaya bangsa, serta merupakan bagian dari upaya untuk meminimalisir dampak negatif dari arus globalisasi yang tidak lagi dapat dihindarkan dewasa ini. Berbagai permasalahan tersebut, tentu saja memerlukan pemecahan, karena dampak globalisasi akan menjadi ancaman yang serius bagi generasi muda bangsa apabila mereka tidak didasari oleh kesadaran akan pentingnya nilai-nilai adat dan tradisi yang berlaku dalam lingkungannya. Fokus kajian dari penelitian ini adalah dikhususkan pada proses ketahanan pangan yang menjadi ciri khas dari masyarakat kampung adat Cireundeu. Penelitian kualitatif ini menggunakan metode etnografi. Adapun hasil yang diperoleh dari penelitian ini menunjukan bahwa kearifan lokal dalam upaya menjaga ketahanan pangan yang dilakukan oleh masyarakat kampung adat Cireundeu yang menjadi salah satu nilai budayanya telah mampu hidup berkembang dalam masyarakat adat tersebut selama ratusan tahun yakni terhitung sejak 1918 hingga saat ini. Kemampuan mereka menjaga ketahanan pangan tersebut tidak lepas dari proses pewarisan budaya yang tetap terjaga dari generasi ke generasi. Nilai budaya tersebut dinilai tidak hanya dapat berkembang didalam budaya mereka saja, akan tetapi dapat berlaku pula pada seluruh umat manusia. Dengan demikian, nilai-nilai budaya lokal tersebut dapat dijadikan sebagai sumber pembelajaran IPS, dengan tujuan untuk menjadikan pembelajaran IPS menjadi lebih bermakna bagi para peserta didik.
\end{abstract}

Kata kunci: kearifan lokal dalam menjaga ketahanan pangan sebagai sumber pembelajaran IPS.

\section{PENDAHULUAN}

Pendidikan IPS (Ilmu Pengetahuan Sosial) merupakan salah satu pendidikan yang memiliki peran penting di dalam upaya pembentukan karakter dan penerapan nilainilai bagi terciptanya manusia Indonesia yang seutuhnya. Penerapan dan pembentukan karakter tersebut menjadi ciri budaya masyarakat Indonesia yang tentu saja merupakan sebuah akumulasi dari nilai-nilai lokal masingmasing suku bangsa yang ada di Indonesia. Upaya tersebut merupakan bagian dari proses pembelajaran IPS.

Dalam Depdikbud (1993) Ilmu Pengetahuan Sosial hakikatnya adalah memberikan kita pelajaran kepada kita semua tentang bagaimana seharusnya hidup bersama. Dengan perkataan lain bahwa IPS membantu kita untuk memahami bagaimana hidup bersama dengan yang lain, seperti bertetangga dan berinteraksi dengan lingkungannya, sehingga secara garis besar kita mampu memupuk rasa kepedulian dengan masalah-masalah sosial, baik dimulai dari keluarga maupun secara lebih luas yaitu masalah sosial dalam masyarakat. Sesuai Kurikulum 1994 bahwa IPS berfungsi untuk mengembangkan kemampuan dan berpikir rasional tentang gejalagejala sosial, mengembangkan negara dan masyarakat Indonesia baik masa lalu dan masa kini. Adapun tujuan dari Ilmu Pengetahuan Sosial (IPS) menurut Effendi (2006 hlm 54) yang diajarkan di berbagai tingkat atau jenjang pendidikan adalah untuk mempersiapkan dan 
mengembangkan peserta didik menjadi bagian bangsa dan anggota masyarakat yang baik. Berkaitan dengan tujuan dari IPS tersebut terdapat beberapa aspek yang medukungnya, yaitu aspek pengetahuan, aspek keterampilan, dan aspek nilai dan sikap.

Menurut Hasan (2010, hlm 8) bahwa: Pendidikan IPS selalu mendapatkan sorotan tajam sebagai mata pelajaran yang dianggap membebani peserta didik. Melalui IPS, peserta didik dijejali dengan berbagai definisi, fakta, nama ahli, dan berbagai pendapat dari para ahli, sehingga pendidikan IPS menjadi corong bagi mereka yang mungkin terpaksa atau tidak memiliki pilihan lain kecuali belajar IPS. Berbagai keluhan tentang IPS terekam dalam berbagai penelitian, keluhan seperti membosankan, tidak menantang pikiran, menambah beban belajar, tidak ada manfaatnya, hanya untuk mereka yang kurang cerdas, hanya untuk mereka yang kuat dalam menghafal, dan materi pelajaran yang tidak dapat digunakan atau tidak berkenaan dengan kehidupan seharihari. Keseluruhan keluhan tersebut semakin menggambarkan bahwa proses pembelajaran IPS terkesan kering dan terlalu monoton.

Pembelajaran IPS selama ini dinilai sebagai suatu kegiatan pembelajaran membosankan, selalu berkaitan dengan aktivitas menghapal fakta-fakta (bersifat hapalan), dsb. Pembelajaran IPS dianggap tidak bermakna (meaningfull) bagi kehidupan sehari-hari peserta didik. Pembelajaran IPS seyogyanya harus mampu mengubah paradigma tersebut. Tugas besar tersebut tentu saja bukan memaksakan metode atau model pembelajaran yang beragam saja, akan tetapi dapat dilakukan dengan menjadikan isu-isu sosial sebagai bahan belajar, terutama yang berkaitan dengan nilai-nilai kearifan lokal dalam masyarakat dan dekat dengan kehidupan peserta didik, sehingga diharapkan melalui pembelajaran yang berlandaskan pada bahan ajar yang lebih menarik, IPS akan jauh lebih menyenangkan dan lebih bermakna.

Salah satu nilai-nilai kearifan lokal yang dapat dikembangkan sebagai bahan belajar IPS tentunya dipilih berdasarkan keunikan dan nilai-nilai sosial yang diharapkan mampu membantu peserta didik melihat dan mempelajari makna atau arti kehidupan dan mengaplikasikannya dalam kehidupan mereka sehari-hari. Penelitian ini bermaksud untuk mengangkat kehidupan masyarakat adat Cireundeu yang memiliki banyak keunikan dan dapat digunakan sebagai sumber belajar IPS di tingkat persekolahan oleh para guru.

Masyarakat adat yang masih memelihara adat dan nilai-nilai tradisi dikenal dengan sebutan kearifan lokal (local wisdom) masih bertahan di tengah-tengah kemajuan zaman yang menghendaki mobilisasi yang serba cepat dan instan, tidak kemudian dianggap sebagai atau berarti kuno atau terbelakang, mengingat apa yang tetap dipertahankan tersebut tetap memiliki alasan yang dianggap masuk akal. Kearifan lokal yang tersirat dalam segala bentuk kehidupan adalah hasil dari proses perjalanan panjang dalam upaya melestarikan adat istiadatnya. Kampung-kampung adat yang mampu bertahan adalah suatu komunitas yang mampu tetap memegang adat istiadatnya, akan tetapi tidak berarti tertutup atau menutup diri dari pengaruh luar komunitas mereka, hanya saja mereka tetap mempertahankan segala sesuatu yang diyakininya lebih kuat pengaruhnya dari perubahan-perubahan yang ada di luar lingkungan mereka. Salah satunya adalah Kampung Adat Cireundeu, dimana masyarakatnya masih memegang teguh tradisi yang oleh masyarakat luar dianggap sesuatu yang berbeda dari keumuman cara hidup mayoritas manusia. Kampung Adat Cireundeu secara administratif terletak di Kelurahan Leuwi 
Gajah Kecamatan Cimahi Selatan Kota Cimahi. Kajian utama dalam penelitian ini, adalah berkaitan dengan ketahanan pangan yang berhasil dilakukan masyarakatnya melalui nilai-nilai religi yang dianut serta diwariskan secara turun-temurun. Sebagian besar masyarakat Cireundeu menganut aliran kepercayaan Madrais atau Sunda Wiwitan. Namun dalam penelitian ini, peneliti tidak bermaksud untuk mengkaji bagaimana aliran tersebut diwariskan dan dilestarikan, akan tetapi lebih kepada mengkaji nilai-nilai religi yang mereka anut untuk mengembangkan ketahanan pangan yang berkembang sehingga diharapkan dapat menjadi sumber informasi pengetahuan yang bermanfaat bagi peserta didik terutama dalam mewujudkan ketahanan pangan yang menjadi bagian dari nilai-nilai kearifan lokal yang ada di Indonesia.

Pembelajaran yang bersumber pada nilainilai kearifan lokal berwawasan pelestarian lingkungan dalam hal mewujudkan ketahanan pangan merupakan pedoman dalam berperilaku peserta didik untuk dapat memotivasi mereka agar dapat mewujudkan kedaulatan pangan yang selama ini menjadi salah satu masalah sosial.

\section{HASIL DAN PEMBAHASAN}

Kearifan lokal secara epistemologi terdiri dari dua kata yaitu kearifan (wisdom) yang berarti kebijaksanaan dan lokal (local) berarti setempat. Local wisdom dipahami sebagai gagasan-gagasan, nilai-nilai, pandanganpandangan setempat yang bersifat bijaksana, penuh kearifan, bernilai baik, yang tertanam dan diikuti oleh anggota masyarakatnya. Menurut Rosidi (2011 hlm 29) Istilah kearifan lokal adalah terjemahan dari "local genius" yang pertama kali diperkenalkan Quaritch Wales tahun 1948-1949 yang mengandung arti "kemampuan kebudayaan setempat dalam menghadapi pengaruh kebudayaan asing pada waktu kebudayaan itu berhubungan".

Adapun ciri-ciri kearifan lokal menurut Ayat Rohaedi (1986 hlm 42) adalah, "mampu bertahan terhadap budaya luar, memiliki kemampuan mengakomodasi unsur-unsur budaya luar, mempunyai kemampuan mengintegrasikan unsur budaya luar ke dalam budaya asli, mempunyai kemampuan mengendalikan, dan mampu memberi arah pada perkembangan budaya". Kearifan lokal merupakan pengetahuan yang secara eksplisit muncul dari periode panjang berevolusi bersama-sama masyarakat dan lingkungannya dalam sistem lokal yang sudah dialami bersama-sama. Proses evolusi yang begitu panjang dan melekat dalam masyarakat dapat dijadikan kearifan lokal sebagai sumber energi potensial dari sistem pengetahuan kolektif masyarakat untuk hidup bersama secara dinamis dan damai. Pengertian ini melihat kearifan lokal tidak sekedar sebagai acuan tingkah laku seseorang, tetapi lebih jauh, yaitu mampu mendominasi kehidupan masyarakat yang penuh keadaban.

Secara substansial, kearifan lokal adalah nilai-nilai yang berlaku dalam masyarakat. Nilai-nilai yang diyakini kebenarannya dan menjadi acuan dalam bertingkah laku seharihari masyarakat setempat. Karena itu, sangat beralasan jika dikatakan bahwa kearifan lokal merupakan entitas yang sangat menentukan harkat dan martabat manusia dalam komunitasnya. Hal itu berarti kearifan lokal yang di dalamnya berisi unsur kecerdasan kreativitas dan pengetahuan lokal dari para elit dan masyarakatnya adalah yang menentukan dalam pembangunan peradaban masyarakatnya.

Masyarakat adat sebagai pendukung warisan budaya terutama generasi tua memang masih mempunyai keinginan atau kecenderungan untuk mempertahankan kebudayaan dimasa lampau sedangkan sebagian besar 
generasi muda cenderung untuk lebih terbuka dan siap mengadakan pembaharuan kebudayaan dengan harapan dapat membentuk pencapaian tujuan hidup mereka. Pada perkembangan selanjutnya, generasi muda cenderung berkesempatan untuk menentang semua hal yang telah berlaku dalam budaya masyarakat adat, meskipun sebenarnya tidak semua nilai-nilai dalam masyarakat adat bersifat tertutup dan tidak sesuai dengan perkembangan zaman. Nilai-nilai yang terdapat dalam kehidupan masyarakat adat juga terkadang universal dan dapat diberlakukan di zaman yang terus berkembang atau dengan kata lain, bahwa sebagian dari nilai-nilai kehidupan masyarakat adat tersebut dapat terus hidup dalam era globalisasi dewasa ini.

Nilai-nilai budaya masyarakat adat dapat diperkenalkan dikancah internasional sebagai warisan budaya bangsa atau khasanah budaya bangsa yang dapat mendorong kemajuan budaya nasional. Karena itu, penting sekali untuk generasi muda menggali nilai-nilai positif dari masyarakat adat. Dalam hal ini, yang kemudian menjadi fokus kajian adalah tentang tradisi dan budaya masyarakat kampung adat Cireundeu dalam membangun dan menjaga ketahanan pangan melalui proses pewarisan budaya hingga saat ini.

Secara umum Masyarakat Kampung Adat Cireundeu merupakan suatu komunitas masyarakat adat yang berada di tengah-tengah masyarakat lainnya yang telah jauh lebih modern. Berbagai keunikan yang terdapat dan berkembang di masyarakat kampung adat ini, menjadi heritage tersendiri bagi kota Cimahi, dan mampu mewakili kota ini untuk bersaing dengan kota-kota lain dalam keikutsertaannya di berbagai festival baik lokal maupun internasional, dengan mengusung keunikan mereka yakni dalam hal mengkonsumsi panganan yang terbuat dari singkong.
Secara historis, para leluhur kampung adat Cireundeu telah memulai merubah konsumsi pangan mereka dari beras ke singkong terhitung sejak tahun 1918. Hal ini didasari oleh pemikiran bahwa mereka tidak boleh terpaku pada satu jenis makanan saja, yakni beras, mengingat bahwa beraslah yang menjadi makanan pokok masyarakat Indonesia secara umum. Adanya pemikiran tersebut didasarkan pula pada kenyataan bahwa ketersediaan bahan pangan di bumi ini begitu beragam. Apabila manusia tetap mengkonsumsi satu jenis makanan saja (beras) maka dikhawatirkan akan terjadi kelaparan dan kemiskinan. Mengingat jumlah makanan (beras) akan mengalami kemerosotan dibandingkan dengan jumlah manusia yang teus bertambah setiap waktunya.

Pemikiran masyarakat Cireundeu tersebut sesuai dengan teori yang dikemukakan oleh Thomas Malthus tentang deret ukur dan deret hitung. Meskipun sebenarnya para leluhur mereka memikirkannya secara sederhana. Berdasarkan hal itu, kemudian para leluhur mereka memutuskan untuk mengajak seluruh kampung beralih dari mengkonsumsi beras ke singkong, tentunya dengan berbagai upaya untuk merubah kebiasaan yang telah lama berlangsung. Peralihan dari beras ke singkong ini baru terwujud secara nyata dan menyeluruh pada tahun 1924. Masyarakat Cireundeu memegang teguh prinsip "teu boga sawah asal boga pare, teu boga pare asal boga beas, teu boga beas asal bisa nyangu, teu nyangu asal dahar, teu dahar asal kuat". Prinsip itulah yang menjadi ciri khas bagi masyarakat cireundeu untuk tetap bertahan mengkonsumsi singkong hingga saat ini.

Potensi kegiatan pengolahan singkong yang dilakukan oleh masyarakat Cireundeu dapat memberikan banyak manfaat salah satunya adalah dapat meingkatkan taraf 
perekonomian warganya. Secara signifikan dibandingkan dengan hanya menjual singkong secara utuh dalam kondisi sebagai bahan mentah. Para wanita baik ibu-ibu maupun remaja telah mampu mengolah singkong menjadi berbagai macam varian makanan yang menarik dan tidak membosankan. Singkong berubah menjadi nasi (rasi), berbagai jenis kue, dan cemilan sehat, hingga mampu menghasilkan jenis bubur untuk makanan bayi yang pada awalnya dipikirkan akan sulit untuk diolah, mengingat sebenarnya jenis singkong yang tunbuh dan dikonsumsi oleh masyarakat Cireundeu adalah singkong racun dengan rasa yang sangat pahit. Akan tetapi, karena kreatifitas masyarakatnya kemudian singkong menjadi layak konsumsi dan tidak menyebabkan keracunan. Hingga saat ini para ibu dan remaja putri di kampung Cireundeu telah mampu menghadirkan serbagai jenis makanan berbahan dasar singkong yang menjadi daya tarik masyarakat lain untuk mengkonsumsi.

Pangsa pasar untuk menjual produk mereka menjadi sangat luas, setiap harinya para wanita ini bekerja mulai dari jam 09.00 pagi hingga pukul 21.00 untuk memproduksi makanan jenis-jenis panganan ringan yang dipesan oleh konsumen yang sengaja datang ke Cireundeu. Masyarakat Cireundeu yang menganut aliran Madrais, menyadari bahwa pemesan olahan singkong mereka adalah orang-orang muslim, maka untuk meyakinkan ke-halalan produk, mereka meminta MUI untuk mengeluarkan sertifikat halal yang akan menjamin kenyamanan dan kepercayaan konsumen muslim tentang produk mereka.

Kemampuan masyarakat kampung adat Cireundeu dalam menjaga ketahanan pangannya, tidak hanya menjadi ciri khas atau keunikan saja bagi image mereka akan tetapi labih jauh upaya mereka juga membuahkan hasil yang manis. Kondisi ekonomi masya- rakat Cireundeu meningkat secara signifikan, setelah mereka berhasil memperkenalkan produk mereka ke masyarakat luar dan diapresiasi luar biasa oleh para konsumen.

Berbagai upaya yang telah dilakukan oleh masyarakat kampung adat Cireundeu terutama dalam membangun dan menjaga ketahanan pangan dengan beralih dari beras ke singkong merupakan bagian dari nilai budaya atau nilai kearifan lokal yang dapat bersifat secara universal. Artinya kondisi ini dapat juga diterapkan pada masyarakat lain di semua wilayah Indonesia. Keputusan untuk tidak bergantung pada satu jenis pangan merupakan pengambilan keputusan yang tepat. Melalui upaya tersebut, masyarakat Indonesia pada umumnya dapat terhindar dari krisis pangan, dan mendapatkan gizi yang seimbang dari berbagai variasi makanan yang dikonsumsi.

Kearifan lokal masyarakat adat Cireundeu dapat dikembangkan menjadi sumber pembelajaran IPS bagi para peserta didik. Merumuskan sumber belajar dari kondisi yang lebih dekat dengan kehidupan sehari-hari peserta didik, diharapkan pembelajaran IPS akan lebih bermakna.

Penerapan nilai-nilai kearifan lokal dalam pembelajaran IPS dapat dialakukan dengan banyak cara, misalnya dengan mengajak peserta didik untuk belajar langsung di lapangan, melihat bagaimana masyarakat adat mengimplementasikan nilai-nilai budayanya, mendiskusikannya dalam kelas, dan mencoba untuk menggali potensi-potensi lain yang ada dilingkungan sekitarnya agar dapat memiliki nilai tambah bagi mereka dan lingkungannya. Belajar secara langsung dengan melibatkan mereka dalam kehidupan masyarakat adat Cireundeu diharapkan akan mampu memicu tingkat kreatifitas para peserta didik dalam melihat peluang maupun potensi yang dapat mereka kembangkan dilingkungannya. 


\section{PENUTUP}

Pewarisan nilai-nilai budaya masyarakat dari generasi ke generasi merupakan hal yang sangat penting untuk tetap menghadirkan nilainilai budaya yang positif dan untuk mencegah hal-hal negatif yang disebabkan oleh arus globalisasi dewasa ini. Implementasi atau penerapan nilai-nilai kearifan lokal suatu masyarakat dalam pembelajaran IPS menjadi bagian yang dapat merubah paradigma belajar IPS yang dinilai membosankan, monoton, menjadi pembelajaran menyenangkan dan bermakna. Selain itu, pembelajaran IPS yang bersumber pada nilai-nilai kearifan lokal diharapkan mampu memberikan wawasan dan pencerahan bagi peserta didik untuk memacu kreatifitas mereka dalam menghadapi masa depan yang akan menuntut mereka untuk dapat berkompetisi atau bersaing dengan masyarakat lain dalam era globalisasi.

Nilai-nilai budaya masyarakat adat Cireundeu cukup relevan dengan kondisi masyarakat Indonesia khusunya masyarakat sunda saat ini, sehingga apabila nilai-nilai tersebut digunakan sebagai sumber belajar IPS akan sangat menarik dan memudahkan guru maupun peserta didik untuk memahami bagaimana seharusnya menghadapi berbagai masalah pangan yang sering melanda bangsa ini. Malalui ketahanan pangan tersebut, diharapkan pembelajaran IPS mampu memberikan pemahaman kepada generasi muda akan pentingnya membangun kesadaran untuk memanfaatkan potensi alam sehingga terbebas dari ketergantungan impor bahan pangan.

\section{DAFTAR PUSTAKA}

Achdiani, Yani. (2004). Sosialisasi dan Enkulturasi Tradisi Penganut Madraisme dalam Keluarga di Kampung Adat Cireundeu, Kota Cimahi. Bandung: Unpad

Aditya, Yupenalis. 2013. Tesis : Nilai-Nilai Kearifan Lokal Masyarakat Cigugur Kuningan Dalam Pelestarian Lingkungan Hidup Sebagai Sumber Belajar Geografi. Bandung: UPI Bandung

Al Muchtar, Suwarma. (2004). Pengembangan Berpikir dan Nilai Dalam Pendidikan IPS. Bandung: Gelar Pustaka Mandiri

Alwasilah, Chaedar. (2009). Pokoknya Kualitatif: Dasar-dasar Merancang dan Melakukan Penelitian Kualitatif. Jakarta : PT Dunia Pustaka Jaya

Dyk, Van. (1962). Pengantar Hukum Adat Indonesia. Bandung : Sumur Bandung

Mulyana,Agus. (2004). Mengartikulasikan Pendidikan Nilai. Bandung:

Rosidi, Ajip.2011. Kearifan Lokal Dalam perspektif Budaya Sunda. Bandung: Kiblat Buku Utama

Sapriya. (2009). Pendidikan IPS: Konsep dan Pembelajaran. Bandung : Alfabeta

Somantri, Numan dkk. (2012). Inovasi Pembajaran IPS. Bandung : Rizki Press

Sumaatmadja, Nursid. (2010). Manusia dalam Konteks Sosial, Budaya dan Lingkungan Hidup. Bandung : Alfabeta 